of the organization to improve its efficiency, the Niger Basin Authority was established in 1980. Its responsibilities cover the harmonization and co-ordination of national development policies; the formulation of the general development policy of the Basin; the elaboration and implementation of an integrated development plan of the Basin; the initiation and monitoring of an orderly and rational regional policy for the utilization of the waters of the Niger River; the design and conduct of studies, researches and surveys; the formulation of plans, the construction, exploitation and maintenance of structure, and the elaboration of projects.

Members. Benin, Burkina Faso, Cameroon, Chad, Côte d'Ivoire, Guinea, Mali, Niger, Nigeria.

Official languages: English, French.

Headquarters: BP 729, Niamey, Niger.

Website: http://www.abn.ne

Executive Secretary: Maj.-Gen. (retd) Collins Remy Umunakwe Ihekire (Nigeria).

\section{Southern African Customs Union (SACU)}

Established by the Customs Union Convention between the British Colony of Cape of Good Hope and the Orange Free State Boer Republic in 1889, the Southern African Customs Union was extended in 1910 to include the then Union of South Africa and British High Commission Territories in Africa and remained unchanged after these countries gained independence. South Africa was the dominant member with sole-decision making power over customs and excise policies until the 2002 SACU Agreement which created a permanent Secretariat, a Council of Ministers headed by a minister from one of the member states on a rotational basis, a Customs Union Commission, Technical Liaison Committees, a SACU tribunal and a SACU tariff board.

Members. Botswana, Lesotho, Namibia, South Africa, Swaziland.

Aims. To promote economic development through regional coordination of trade.

Headquarters: Private Bag 13285, Windhoek, Namibia.

Website: http://www.sacu.int

Email:info@sacu.int

Executive Secretary: Tswelopele Cornelia Moremi (Botswana).

\section{Southern African Development Community (SADC)}

The Southern African Development Co-ordination Conference (SADCC), the precursor of the Southern African Development Community (SADC), was formed in Lusaka, Zambia on 1 April 1980, following the adoption of the Lusaka Declaration-Southern Africa: Towards Economic Liberation-by the nine founding member states.

Members. The nine founder member countries were Angola, Botswana, Lesotho, Malawii, Mozambique, Swaziland, Tanzania, Zambia and Zimbabwe. The Democratic Republic of the Congo, Madagascar, Mauritius, Namibia, the Seychelles and South Africa have since joined. The Seychelles left in July 2004 but rejoined in Aug. 2007. As a result there are now 15 members.
Aims and Activities. SADC's Common Agenda includes the following: the promotion of sustainable and equitable economic growth and socio-economic development that will ensure poverty alleviation with the ultimate objective of its eradication; the promotion of common political values, systems and other shared values that are transmitted through institutions that are democratic, legitimate and effective; and the consolidation and maintenance of democracy, peace and security.

In contrast to the country-based co-ordination of sectoral activities and programmes, SADC has now adopted a more centralized approach through which the 21 sectoral programmes are grouped into four clusters; namely: Trade, Industry, Finance and Investment; Infrastructure and Services; Food, Agriculture and Natural Resources; Social and Human Development and Special Programmes.

SADC has made significant progress in implementing its integration agenda since the 1992 Treaty came into force. Since then, more than 20 Protocols to spearhead the sectoral programmes and activities have been signed. Those Protocols that have entered into force include: Immunities and Privileges; Combating Illicit Drugs; Energy; Transport, Communications and Meteorology; Shared Watercourse Systems; Mining; Trade; Education and Training; Tourism; and Health.

Official languages: English, French, Portuguese.

Headquarters: SADC House, Plot No. 54385, Central Business

District, Private Bag 0095, Gaborone, Botswana.

Website: http://www.sadc.int

Email: registry@sadc.int

Executive Secretary: Tomaz Augusto Salomão (Mozambique).

\section{West African Development Bank (BOAD)}

The West African Development Bank (Banque Ouest Africaine de Développement) was established in Nov. 1973 by an Agreement signed by the member states of the West African Monetary Union (UMOA), now the West African Economic and Monetary Union (UEMOA).

Aims. To promote balanced development of the States of the Union and to achieve West African economic integration.

Members. Benin, Burkina Faso, Côte d'Ivoire, Guinea-Bissau, Mali, Niger, Senegal, Togo.

Official language: French.

Headquarters: 68 avenue de la Libération, Lomé, Togo.

Website (French only): http://www.boad.org

Email: boadsiege@boad.org

President: Christian Adovèlandé (Benin).

\section{West African Economic and Monetary Union (UEMOA)}

Founded in 1994, the UEMOA (Union Economique et Monétaire Ouest Africaine) aims to reinforce the competitiveness of the economic and financial activities of member states in the context of an open and rival market and a rationalized and harmonized juridical environment; to ensure the convergence of the macroeconomic performances and policies of member states; to create a common market among member states; to co-ordinate 